\title{
OPTIONS MARKETS AND THE INFORMATION CONTENT OF ACCOUNTING EARNINGS RELEASES*
}

\author{
Douglas J. SKINNER \\ University of Michigan, Ann Arbor, Michigan 48109-1234, USA \\ Received November 1989, final version received September 1990
}

\begin{abstract}
This study documents that the information content of firms' accounting earnings releases is lower, on average, after exchange-traded options are listed on their stocks. The results are consistent with predictions that: (i) options provide investors with a more cost-effective tool for trading on information, so that (ii) more private information is produced about these firms after options listing, so that (iii) the information in earnings releases is preempted to a greater extent after options listing. However, because options listing is endogenous, it is difficult to infer from this evidence that options listing causes these informational changes.
\end{abstract}

\section{Introduction}

This paper examines whether a firm's listing on an options exchange is associated with changes in the information content of its accounting earnings releases. For the majority of sample firms, the size of the stock-price reaction to accounting earnings releases is smaller after exchange-traded options are listed on their stocks. This evidence is consistent with the view that options listing improves the 'informational efficiency' of the market for the underlying stock.

\footnotetext{
*This paper is based on my Ph.D. dissertation, completed at the University of Rochester. I am grateful to my dissertation committee, Ray Ball, G. William Schwert, and especially Ross Watts (chairman) for their helpful comments and encouragement. I have also benefited from the comments of participants at seminars at the Australian Graduate School of Management, the University of Chicago, Harvard University, Macquarie University, MIT, the University of Michigan, Northwestern University, the University of Pennsylvania, the University of Rochester, and Sydney University, and in particular from those of Victor Bernard, Peter Easton, John Elliott, Anthony Greig, Paul Healy, Robert Holthausen, Eugene Imhoff, S.P. Kothari (a referee), Thomas Lys, Patricia O'Brien, Katherine Schipper, Paul Seguin, Karen Wruck, Jerold Zimmerman (the editor), and an anonymous referee. I am also grateful to Eugene Imhoff and Mark Zmijewski for sharing their Value Line forecast data with me and to Lynch, Jones \& Ryan for providing me with access to the $\mathrm{I} / \mathrm{B} / \mathrm{E} / \mathrm{S}$ database. Partial funding was provided by the Deloitte, Haskins \& Sells Foundation. I alone am responsible for any errors.
} 
More specifically, the test procedures focus on two measures of the information content of accounting earnings releases. I find that:

(1) The stock-price reaction to earnings releases conditional on unexpected earnings (the 'earnings response coefficient') declines from 0.69 before options listing to 0.41 after options listing. Thus, an earnings surprise equal to $1 \%$ of the stock price generates an abnormal two-day return of $0.69 \%$ ( 35 cents on a $\$ 50.00$ stock) before options listing, but only $0.41 \%$ (20 cents on a $\$ 50.00$ stock) after options listing.

(2) The size of the stock-price reaction to accounting earnings releases (the average absolute value of the abnormal returns) is $0.33 \%$ smaller after options are listed on these firms' stocks, falling from $2.85 \%$ before options listing to $2.52 \%$ after options listing. This result implies that an investor holding a $\$ 50.00$ stock would experience a stock-price reaction that is 16 cents smaller, on average, after options are listed on the stock.

In addition, I find that options listing is associated with an increase in the number of analysts following these firms. Overall, the evidence is consistent with the firm being more 'closely followed' after options listing, so that the information contained in earnings announcements is better anticipated, reducing their potential information content.

An important caveat applies. I find that firms listed on options exchanges are unusual along several dimensions (principally size and risk) and that optioned firms change in systematic ways between pre- and post-listing periods. It is possible that these systematic changes are related to the options exchanges' decision to list the firm and to the observed change in the information content of these firms' earnings releases. In other words, options listing is endogenous, which makes it difficult to conclude that options listing causes changes in the information content of these firms' earnings releases.

Section 2 of the paper sets out the paper's hypothesis development. Section 3 discusses the sample of firms used in the empirical tests. Section 4 presents evidence of the change in information content over time. Section 5 explores the alternative ('selection bias') explanation for the decline in information content. Section 6 concludes the paper with a summary and discussion of the results.

\section{Hypothesis development}

To a large extent, investors anticipate the information contained in accounting earnings releases. The evidence in Foster (1977) implies that approximately $70 \%$ of the stock-price adjustment associated with quarterly earnings numbers occurs before the earnings announcement. If options trading creates additional incentives for investors to collect private information about firms, then the extent to which investors anticipate the informa- 
tion contained in earnings releases is likely to increase after options listing, reducing the potential information content of the earnings releases. I examine the hypothesis that, after options are listed on a firm's stock, a larger proportion of the total stock-price adjustment associated with the information in its earnings releases takes place before earnings are announced, so that there is a smaller stock-price adjustment at the time of the release.

Black (1975) and Cox and Rubinstein (1985) argue that, for traders with private information ('information traders'), exchange-traded put and call options offer a lower-cost alternative to trading directly in the underlying stock. First, while call options written on common stocks are equivalent to levered positions in the stock, taking a long position in call options is likely to be cheaper than borrowing to purchase the underlying stock for two reasons. (1) Cox and Rubinstein (1985, p. 50) argue that the borrowing rates implicit in options prices are often more favorable than those available to most investors acting on their own behalf. ${ }^{1}$ (2) Margin requirements limit the amount an investor can borrow against a stock to a fixed percentage of its value (usually $50 \%$ ). For some call options, especially those well out of the money, the amount of borrowing implicit in the position can exceed 50\%, even if the investor is not allowed to borrow against the call position.

Second, some restrictions on short-selling stocks are mitigated by options trading. For example, the 'Uptick Rule' specifies that a short-sale can only occur on a plus or zero-plus tick; that is, after a share-price increase or after a no-trade preceded by an increase. There is no such restriction on options markets. Similarly, margin requirements typically prevent an individual investor from obtaining full use of the proceeds from a short-sale of stock. By buying put options or writing call options, the investor can obtain payoffs that are equivalent to short stock positions, but which effectively allow the investor to reinvest a larger proportion of the sale proceeds.

Third, if an investor has certain types of private information, options can be used to take advantage of the information in ways not available by trading in the stock alone. For example, private knowledge about future changes in a firm's financing and investment choices will likely enable an investor to arrive at a better forecast of the stock's future return volatility than that implicit in current options prices.

Thus, there are several reasons to expect that options trading increases investors' incentives to gather private information about firms. Absent options trading, investors with firm-specific private information take advantage of that information by trading in the appropriate firm's stock. Once the firm is listed on an options exchange, investors can execute trades in the stock, in

\footnotetext{
${ }^{1}$ This occurs because (i) large market participants generally are able to borrow and lend on more favorable terms than individual investors, and (ii) the borrowing and lending rates applicable to these large market participants are those implicit in options prices, i.e., these participants effectively set options prices.
} 
options written on the stock, or by taking a combined stock/options position. Whichever trading vehicle they choose, however, it is likely that the stock's price will change quickly to reflect the new private information. ${ }^{2}$ This follows because inter-market arbitrage opportunities between stock and options markets are likely to be 'quickly' eliminated. ${ }^{3}$ If this is in fact the case, and if it is also true that options trading increases investors' private information collection activities, then more private information will be reflected in stock prices after options are listed on firms' stocks. This is the key testable proposition in the paper. [This proposition relies on arguments that investors generate a larger amount of private information about firms after options are listed on their stocks. Diamond and Verrecchia (1987) arrive at a similar proposition based on hypothesized changes in the speed with which security prices adjust to reflect a given amount of private information around the time options are listed on stocks.]

\section{Sample selection}

The sample comprises all firms listed on the Chicago Board Options Exchange (CBOE) and American Stock Exchange (AMEX) options exchange over the April 1973 through December 1986 period, subject to the following restrictions.

(1) Earnings-announcement dates and earnings-per-share data are available on Standard and Poor's Compustat Quarterly Industrial File (Compustat) for at least seven of the ten consecutive quarterly earnings announcement dates on either side of the options listing date. (Thus, these data must be available for a minimum of 17 of the 20 possible quarterly earnings announcements.) The announcement dates are verified by reference to the Wall Street Journal Index and the earnings-per-share data by reference to Moody's Handbook of Common Stocks.

(2) At least 100 daily returns are available on the Center for Research in Security Prices (CRSP) NYSE-AMEX daily returns file in the market-model estimation period. The market-model estimation period is the 200 -trading-day

\footnotetext{
${ }^{2}$ This assumes that private information gets reflected quickly in security prices through the trading activity of informed traders [as in Glosten and Milgrom (1985) for example]. If this view is correct, security prices would never deviate from their 'correct' or 'fundamental' values, conditional on informed traders' private information. This is a strong position to take, especially given recent debate about the ability of rational bubbles, fads, etc. to influence asset prices [see, e.g., Camerer (1989)].

${ }^{3}$ Stephan and Whaley (1990) report that, on average, pricing discrepancies between the stock and options markets persist for only 15 to 20 minutes.
} 
period beginning 220 days before the earnings-announcement date and ending 21 days before the earnings-announcement date. ${ }^{4}$

(3) Announcement-period returns are available on the $C R S P$ daily returns file. The announcement period comprises days -1 and 0 relative to the Compustat earnings-announcement date.

Two hundred and fourteen firms meet these requirements, yielding a total of 4,180 firm-quarter observations. In addition, for some test procedures I require that forecasts of quarterly earnings per share are available from the Value Line Investment Survey (Value Line) for at least 12 of the 20 possible quarters. There are 212 firms with data available for these tests.

Table 1 shows the distribution through time of options listing dates for the 214 optioned firms. The listings tend to cluster in certain years, reflecting the process by which the Securities and Exchange Commission (SEC) approved expansion of the options trading programs. The surge in 1975 is due to the start of options trading on the AMEX in that year (the CBOE started in 1973), while the relative dearth of listings in 1977-1979 reflects the SEC 'moratorium' on any expansion of options trading that extended over those years. Table 1 also reports descriptive information on these firms' size (market value of equity) and betas. On average, these firms are both large and relatively risky. The median firm is in the 88th fractile of the size distribution of all NYSE firms in the listing year, and the average firm has an equity beta of 1.27 . The 214 firms are in 43 two-digit SIC industries; the most firms in any one two-digit industry is 26 (12\% of the total).

Tests of the hypothesis require an analysis of these firms' returns and earnings series for periods before and after options listing. However, because the sample listing dates are clustered in calendar time (34\% in 1975), an alternative explanation for any observed change in the information content of these firms' earnings is that it is a market-wide phenomenon. To address this possibility, I also report results for a time-matched group of firms that I refer to collectively as the 'random' sample.

The random sample is constructed as follows. First, I splice together various versions of the Compustat Quarterly Industrial File to obtain a listing of all firms with any earnings-announcement dates available on the file during the 1971 through 1987 period. Firms are eliminated from this list if they do not have a set of at least 17 consecutive earnings-announcement dates during the 1971-1987 period. Those firms that remain are then randomly assigned

\footnotetext{
${ }^{4}$ The market model is estimated over days -220 through -21 , defined relative to the announcement date, and excluding missing returns and prior announcement periods. Continuously compounded returns and the CRSP (NYSE-AMEX) value-weighted market index are used, although the results are not sensitive to these choices. Also, the results are not materially affected if I use Scholes and Williams (1977) or Fowler and Rorke (1983) estimators in place of ordinary least-squares estimators.
} 
Table 1

Distribution through calendar time of dates on which exchange-traded stock options were listed on 214 sample firms. Descriptive statistics for the size and nondiversifiable risk of these firms are also shown."

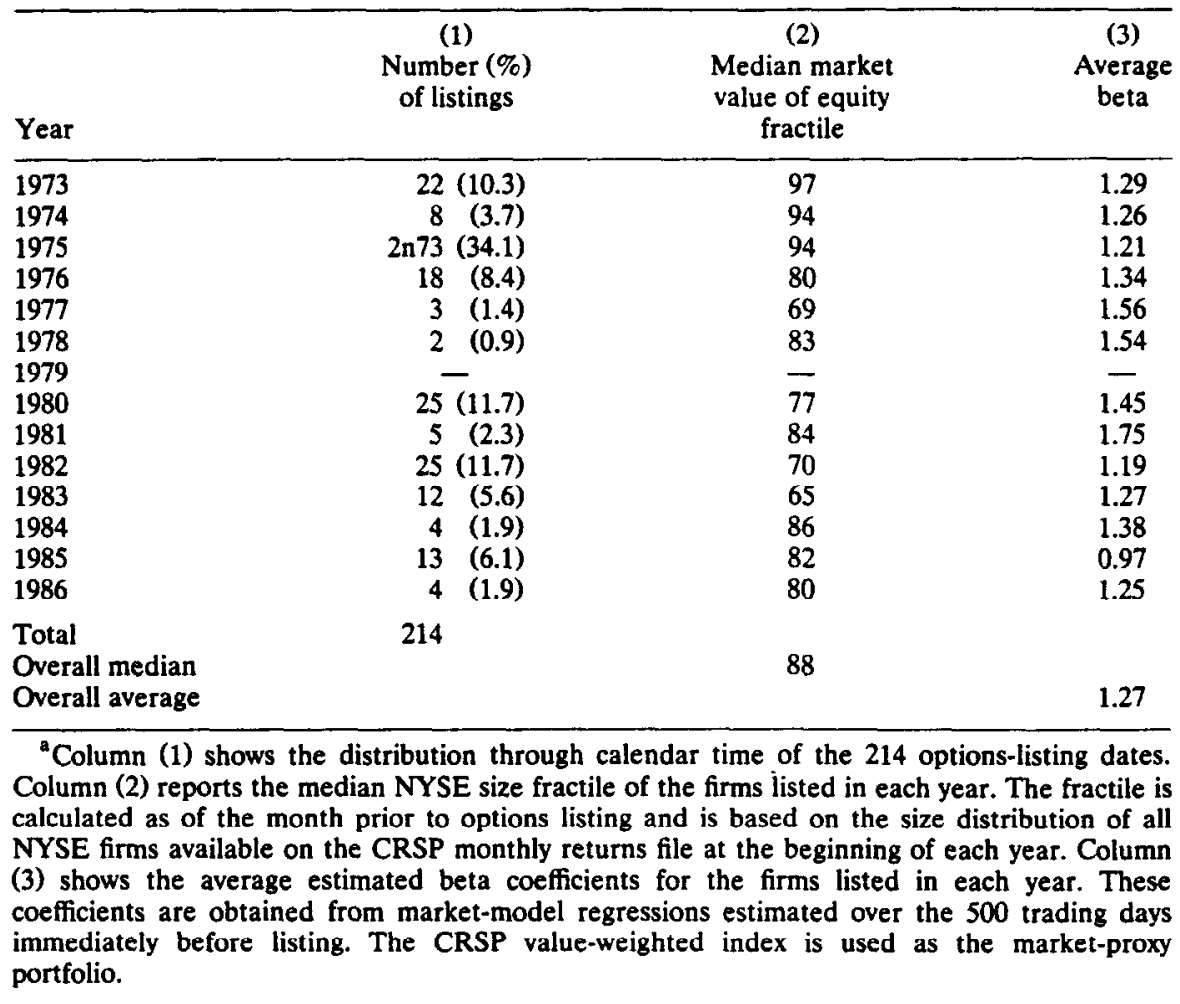

one of the 82 sample options listing dates so that the proportion of firms with any given listing date is the same as for the original sample. (Optioned firms may be included here, but only if the date to which they are assigned is at least five years away from their actual option listing date.) After imposing the same data requirements as described above, a sample of 620 firms remains. ${ }^{5}$ For this sample of firms, the proportion of firms with each of the 82 listing dates is close to that for the original sample of 214 firms. The random sample therefore provides a benchmark for assessing whether or not any observed changes for the optioned firms are driven by market-wide changes. (The firms in the random sample are, on average, both smaller and less risky than the optioned firms. The average (median) firm in the random sample has an

\footnotetext{
SI do not collect Value Line forecasts for the random sample of firms.
} 
equity beta of $0.80(0.75)$ and falls in the 51 st (52nd) fractile of the size distribution of all NYSE firms.)

\section{Changes in the information content of earnings releases}

Section 4.1 provides evidence on how the stock-price reaction to earnings releases, conditional on the size of earnings surprises, changes around the time of options listing. Section 4.2 reports on whether the size of the stock-price reaction to earnings releases changes around the time of options listing. To supplement the stock-price evidence, section 4.3 provides evidence on how the number of analysts following the stock changes around the time of options listing.

\subsection{Conditional information content}

To address the hypothesis that the information content of earnings releases is lower after options listing, I first present evidence of how the stock-price reaction to earnings releases - conditional on the size of the earnings surprise - changes around the time of options listing. Specifically, I regress announcement-period abnormal returns on unexpected earnings so that the regression slope coefficient measures the stock-price reaction to earnings releases, conditional on unexpected earnings. Because the market's expectation of earnings is not observable, I employ Value Line earnings forecasts as my proxy variable for the market's expectation of quarterly earnings. Previous research indicates that forecast errors conditioned on analyst expectations are generally smaller than those from other, timeseries-based, expectations models [Brown et al. (1987a), O'Brien (1988)].

According to the hypothesis, the market anticipates a larger proportion of the information contained in earnings releases after options listing. If this is the case, measurement error in the Value Line proxy for unexpected earnings will increase after options listing, because the accuracy of the market's earnings prediction improves (becomes more precise) while that of the Value Line analysts does not. That is, while the accuracy of the Value Line forecasts relative to actual earnings realizations does not change around the time of options listing (see below), the Value Line forecasts contain more measurement error relative to the market's consensus earnings expectation after options listing. It is this market expectation that is important, since this is the earnings expectation that is impounded in stock prices just before earnings releases. Therefore, I expect to observe a smaller slope coefficient in the period after options listing, as increased measurement error attenuates the size of the measured coefficient.

Brown et al. (1987b) regress announcement-period abnormal returns on measures of unexpected earnings for large and small firms and find smaller 
slope coefficients and $R$-squared values for the large firms. They interpret this as evidence that measurement error in their unexpected-earnings proxy (they also use Value Line forecasts) is positively related to firm size, because 'larger firms are subject to closer scrutiny by equity analysts and earnings information of large firms generally is available earlier to the market' (p. 178). In other words, the Value Line forecasts contain more measurement error for the larger firms because the extent to which the market anticipates earnings information increases with firm size. The Brown et al. argument for large vs. small firms is analogous to the argument here with respect to options listing.

Before discussing the regression results, table 2 provides summary statistics on the age and accuracy of the Value Line forecasts for periods before and after options listing. This evidence is important because interpretation of the regression evidence relies on the fact that the accuracy of the Value Line forecasts, relative to actual earnings realizations, does not change around the time of options listing. Previous research indicates that, on average, analyst forecasts perform worse as earnings expectations the more dated they become; more timely forecasts are generally more accurate [Brown et al. (1987a), O'Brien (1988)]. Therefore, if the average age of the forecasts changes around the time of options listing, this would indicate a likely change in measurement error. The evidence in table 2, however, indicates that this is not the case. The average age of the forecasts is $\mathbf{3 0}$ trading days both before and after options listing (the medians are 32 and 33 trading days, respectively). ${ }^{6}$

The bottom part of table 2 reports on the size of the Value Line forecast errors before and after options listing. The size of the forecast errors is measured as the absolute value of the difference between actual earnings per share and the corresponding Value Line forecast, divided by stock price two days before the earnings release. There is no evidence that analysts are more or less accurate after options listing. The average forecast error is $0.62 \%$ of stock price both before and after options listing. The median forecast error increases from $0.21 \%$ of stock price before listing to $0.23 \%$ afterwards, but the change is not significant at the $5 \%$ level. Overall, there is little in table 2 to indicate a systematic change in the accuracy of Value Line forecasts, relative to actual earnings, over time.

To gauge whether the regression slope coefficient changes significantly around the time of options listing, I regress the announcement-period abnormal returns on the unexpected-earnings measure (actual earnings per share less the Value Line Forecast divided by stock price two days before the announcement) and on the same unexpected-earnings measure multiplied by

\footnotetext{
${ }^{6}$ Brown et al. (1987b, p. 168) report that, for their sample, Value Line forecasts are made approximately 39 calendar days before the earnings announcement.
} 
Table 2

Descriptive information for Value Line forecasts of quarterly earnings per share during periods before and after options are listed on the stocks of 214 sample firms. ${ }^{\text {a }}$

\begin{tabular}{lccc}
\hline & $\begin{array}{c}(1) \\
\text { Before } \\
\text { options } \\
\text { listing }\end{array}$ & $\begin{array}{c}\text { (2) } \\
\text { After } \\
\text { options } \\
\text { listing }\end{array}$ & $\begin{array}{c}\text { (3) } \\
\text { Test statistic } \\
\text { for } \\
\text { difference }\end{array}$ \\
\hline $\begin{array}{l}\text { Observations } \\
\begin{array}{l}\text { Forecast age } \\
\text { (trading days) }\end{array}\end{array}$ & 2005 & 2093 & \\
$\begin{array}{l}\text { Average } \\
\text { Median }\end{array}$ & 29.7 & 30.0 & $t=-0.49$ \\
$\begin{array}{l}\text { Forecast accuracy } \\
\text { (absolute value } \\
\text { of forecast }\end{array}$ & 33.0 & 32.0 & $Z=-0.50$ \\
$\begin{array}{l}\text { error as a } \\
\text { percentage } \\
\text { of stock price) }\end{array}$ & & & \\
$\begin{array}{l}\text { Average } \\
\text { Median } \\
\text { Maximum }\end{array}$ & & & \\
\hline
\end{tabular}

${ }^{\text {a }}$ The top part of the table reports summary statistics for the age of the Value Line forecasts of quarterly earnings per share, where the age of a forecast is the number of trading days between the date the forecast is published in the Value Line Investment Survey and the earnings announcement date. The bottom part of the table reports summary statistics for the size of the analyst forecast errors. This number is defined as the absolute value of the difference between the earnings realization $\left(E P S_{i t}\right.$ ) and the most recently available earnings forecast from the Value Line Investment Survey $\left(V L_{i \ell}\right)$ deflated by share price two days before the earnings announcement $\left(P_{i t}\right)$, i.e.,

$$
U E_{i t}=\left(E P S_{i t}-V L_{i t}\right) / P_{i t} .
$$

The test statistics are two-sample $t$ (Wilcoxon) tests of the null hypothesis that the sample averages (medians) are the same in each period. The $t$-test does not rely on the assumption that the population variances are equal in each period, but does assume that the observations are independent and that they come from populations that are normally distributed. The Wilcoxon test assumes that the observations are independent and that the distribution of the difference between measures is symmetric.

a dummy variable coded zero for firm/quarters before options listing and one for firm/quarters after options listing. Thus, the coefficient on the multiplicative dummy variable measures the change in the slope coefficient from before to after options listing. The results of this regression (with $t$-statistics in parentheses) are as follows:

$$
P E_{i t}=\underset{(0.65)}{0.00}-\underset{(-0.99)}{0.00} \text { Dummy }+\underset{(11.6)}{0.69} U E_{i t}-\underset{(-3.2)}{0.28\left(U E_{i t}\right.} \text { *Dummy), }
$$

Adjusted $R^{2}=0.0407, \quad$ Observations $=4,176$. 
The regression results are consistent with the hypothesis. The regressionslope coefficient declines from 0.69 before options listing to 0.41 after listing. ${ }^{7}$ Thus, an earnings surprise equal to $1 \%$ of the stock price generates an abnormal two-day return of $0.69 \%$ ( 35 cents on a $\$ 50.00$ stock) before options listing, but only $0.41 \%$ ( 20 cents on a $\$ 50.00$ stock) after options listing. The change in the slope coefficient is statistically significant at the $1 \%$ level $(t=-3.2)$. Overall, the decline in the regression slope coefficient is both economically and statistically significant, which is consistent with the hypothesis.

\subsection{Unconditional information content}

To supplement the regression tests, table 3 reports evidence of how the size of the stock-price reaction to earnings releases changes around the time of options listing. More specifically, table 3 summarizes the distribution across firms of the absolute value of the announcement-period abnormal returns. $^{8}$ As discussed above, I collect a sample of quarterly earningsannouncement dates for each firm in each period (before and after options listing). This enables me to calculate the average absolute value of the prediction error for each firm in each period. The table reports summary statistics for the distribution of these averages across firms. For comparison purposes, the table also reports results for the sample of nonoptioned firms.

The results in table 3 indicate that, on average, the measured information content of the optioned firms' earnings releases is smaller after options listing. For these firms, the average size of the prediction error declines from $2.85 \%$ to $2.52 \%$ and the median size of the prediction error from $2.62 \%$ to $2.38 \%$. These changes are significant at the $0.1 \%$ level using single-sample $t$ and Wilcoxon tests, respectively. While statistically significant, these changes are not large in economic magnitude. For example, these results imply that an investor holding a $\$ 50$ stock would experience a stock-price reaction that is 16 cents $(0.33 \%)$ smaller, on average, after options are listed on the stock. Finally, the decline in information content does not pervade the sample: $58 \%$ of the 214 firms experience a decline in the average absolute value of the prediction errors after listing.

\footnotetext{
${ }^{7} 1$ obtain these results after deleting three observations with extreme earnings surprises of $-0.311,0.259$, and 0.496 . The overall results, however, are not greatly affected if $I$ retain these observations: the slope coefficient declines from 0.55 before options listing to 0.17 after listing ( $\boldsymbol{t}$-statistic for difference $=-5.4$ ).

${ }^{8}$ An alternative measure of information content is the $U$-statistic developed by Patell (1976). I do not report results on this measure because of the problems described by Marais (1984). Nevertheless, I have calculated $U$-statistics and the results are qualitatively similar to those obtained using the absolute value of the prediction errors.
} 
Table 3

The absolute value of the stock-price adjustment to quarterly accounting earnings releases in periods before and after options are listed on the stocks of 214 sample firms. (Table also shows comparison results for a time-matched sample of 620 nonoptioned firms. $)^{2}$

\begin{tabular}{lccc}
\hline & $\begin{array}{c}(1) \\
\text { Before } \\
\text { options } \\
\text { listing }\end{array}$ & $\begin{array}{c}\text { (2) } \\
\text { After } \\
\text { options } \\
\text { listing }\end{array}$ & $\begin{array}{c}\text { (3) } \\
\text { Difference } \\
\text { ( } p \text {-value) }\end{array}$ \\
\hline $\begin{array}{l}\text { (i) Optioned firms } \\
\text { Average }\end{array}$ & & $2.52 \%$ & $0.33(0.001)$ \\
10th fractile & $2.85 \%$ & $1.32 \%$ & $0.24(0.001)$ \\
Median & $1.47 \%$ & $2.38 \%$ & $125[58 \%]$ \\
90th fractile & $2.62 \%$ & $3.88 \%$ & \\
Number of declines & $4.47 \%$ & & $0.06(0.17)$ \\
\hline & & $2.64 \%$ & $0.06(0.12)$ \\
Average & $(i i)$ Nonoptioned firms & $1.27 \%$ & $327[53 \%]$ \\
10th fractile & $2.70 \%$ & $2.28 \%$ & \\
Median & $1.26 \%$ & $4.35 \%$ & \\
90th fractile & $2.37 \%$ & & \\
Number of declines & $4.56 \%$ & & \\
\hline
\end{tabular}

(iii) Optioned us. nonoptioned firms

Two-sample

t-tests

Two-sample

Wilcoxon tests

$$
\begin{array}{rlrl}
t & =1.38 & t & =-1.25 \\
Z & =1.97^{\mathrm{b}} & Z & =0.30
\end{array}
$$$$
t=2.43^{\mathrm{b}}
$$$$
Z=2.14^{\mathrm{b}}
$$

${ }^{a}$ The table reports the distribution across firms of the average absolute value of the prediction errors calculated from a sample of earnings-announcement periods for each firm in each period. The prediction errors are calculated using a two-day earnings-announcement period (days -1 and 0 ). The market model is estimated over days -220 through -21 , defined relative to the announcement date and excluding missing returns and prior announcement periods. Continuously compounded returns and the CRSP (NYSE-AMEX) value-weighted market index are used. Column (3) reports the mean (median) of the distribution of differences and the corresponding one-tailed $p$-value from a single-sample $t$ (Wilcoxon) test of the null hypothesis that the mean (median) difference equals zero. The single-sample $t$ (Wilcoxon) test assumes that the differences comprise independent drawings from an underlying normal (symmetric) distribution. The two-sample $t$-test at the bottom of the table does not rely on the assumption that the population variances are equal in each period, but does assume that the observations are independent and that they come from populations that are normally distributed. The two-sample Wilcoxon test assumes that the observations are independent and that the distribution of the difference between measures is symmetric.

${ }^{\mathrm{b}}$ Significant at the $5 \%$ level, two-tailed test. 
The results for the nonoptioned firms in the lower half of table 3 provide assurance that the decline in information content for the optioned firms is not a market-wide phenomenon. For the nonoptioned firms, the average (median) size of the prediction errors is $2.70 \%$ (2.37\%) before listing and $2.64 \%(2.28 \%)$ after listing. Neither of these changes is significant at the $10 \%$ level. Moreover, as the two-sample $t$ and Wilcoxon tests at the bottom of the table indicate, the sample of differences (from before to after options listing) in information content is significantly larger for the optioned firms than it is for the nonoptioned firms. Around half (53\%) of the nonoptioned firms experience a decline in information content, a proportion that is significantly smaller (using a binomial test) than the corresponding proportion for the optioned firms.

The tests in table 3 address only the stock-price reaction to these firms' earnings releases. The analysis in section 2 , however, makes predictions about the size of the stock-price reaction to earnings releases as a proportion of the total stock-price adjustment associated with the information in the current quarter's earnings. According to the earlier analysis, this proportion should decline after options listing, as more of the information contained in the earnings announcement is generated privately prior to its release.

As a measure of the total stock-price adjustment associated with the information in the current quarter's earnings, I cumulate market-model prediction errors over the 61-day period culminating in the earnings release, $C P E(-60,0)$. As before, the stock-price adjustment to the earnings release is calculated as the two-day cumulative prediction error, $C P E(-1,0)$. For each firm-quarter, $I$ then take the absolute value of each number and form the ratio $A B S[C P E(-1,0)] / A B S[C P E(-60,0)]$. I refer to this ratio as the 'adjustment ratio'. On average, I expect the adjustment ratio to be smaller after options listing for the optioned firms.

The absolute value of the cumulative prediction errors, along with the adjustment ratios, are reported in table 4 . [Notice that the average two-day prediction errors in table 4 are not the same as those in table 3 because, to accommodate the longer preannouncement cumulation period, the marketmodel estimation period is now $(-220,-61)$.]

The mean and median 61-day unsigned cumulative prediction errors (CPEs) decline after options listing for both optioned and nonoptioned firms. The decline in these $C P E$ s is similar in terms of both magnitude and statistical significance for optioned and nonoptioned firms, indicating that it is likely a market-wide phenomenon. Consistent with table 2, the decline in the size of the announcement-period $C P E$ s is larger and statistically significant only for the optioned firms. Finally, although the median adjustment ratio declines from 0.221 to 0.209 for the optioned firms, the change is not significant at the $5 \%$ level. This result is inconsistent with my predictions. 
Table 4

Proportion of the stock-price adjustment to accounting earnings releases that occurs at the date of release (days $-1,0$ ) to the total stock-price adjustment for the quarter (days $-60, \ldots, 0$ ) for 214 optioned firms. (Results for a time-matched sample of 620 nonoptioned firms are shown for comparison purposes. $)^{\mathrm{a}}$

\begin{tabular}{|c|c|c|c|}
\hline & $\begin{array}{c}\text { (1) } \\
\text { Before } \\
\text { options } \\
\text { listing }\end{array}$ & $\begin{array}{c}\text { (2) } \\
\text { After } \\
\text { options } \\
\text { listing }\end{array}$ & $\begin{array}{c}\text { (3) } \\
\text { Wilcoxon } \\
\text { p-value } \\
\text { (two-tailed) }\end{array}$ \\
\hline \multicolumn{4}{|c|}{ (i) Optioned firms } \\
\hline Observations & 2056 & 2122 & \\
\hline $\begin{array}{c}\text { ABSICPE }(-1 \\
\text { Average } \\
\text { Median }\end{array}$ & $\begin{array}{l}2.87 \% \\
2.03 \%\end{array}$ & $\begin{array}{l}2.52 \% \\
1.83 \%\end{array}$ & $p=0.002^{\mathrm{h}}$ \\
\hline $\begin{array}{c}\text { ABSICPE }(-6 \\
\text { Average } \\
\text { Median }\end{array}$ & $\begin{array}{r}12.85 \% \\
9.63 \%\end{array}$ & $\begin{array}{r}11.82 \% \\
9.29 \%\end{array}$ & $p=0.086^{c}$ \\
\hline Median ratio & 0.221 & 0.209 & $p=0.29$ \\
\hline \multicolumn{4}{|c|}{ (ii) Nonoptioned firms } \\
\hline Observations & 6050 & 6133 & \\
\hline $\begin{array}{c}A B S[C P E(-1 \\
\text { Average } \\
\text { Median } \\
A B S[C P E(-6\end{array}$ & $\begin{array}{l}2.70 \% \\
1.81 \%\end{array}$ & $\begin{array}{l}2.65 \% \\
1.77 \%\end{array}$ & $p=0.148$ \\
\hline $\begin{array}{l}\text { Average } \\
\text { Median }\end{array}$ & $\begin{array}{l}13.59 \% \\
10.18 \%\end{array}$ & $\begin{array}{r}13.21 \% \\
9.81 \%\end{array}$ & $p=0.064^{c}$ \\
\hline Median ratio & 0.184 & 0.184 & $p=0.71$ \\
\hline
\end{tabular}

${ }^{a}$ The table reports the absolute value of daily market-model prediction errors cumulated over two periods: (i) the earnings-announcement period, $C P E(-1,0)$, and (ii) the 60-day period culminating in the release, $C P E(-60,0)$. I also calculate the ratio of these numbers to measure the proportion of total adjustment that occurs at the time earnings are announced. The statistics reported describe the distribution of these numbers over all firm-quarters in each subperiod. Note that the size of the two-day abnormal returns differs slightly from those shown in table 3 because I employ a different market-model estimation period here: to accommodate the 61-day pre-announcement window, the estimation period here is -220 to -61 rather than -220 to -21 as it is in table 3. Column (3) reports $p$-values from a two-sample Wilcoxon test of the null hypothesis that the medians are equal in each period. This test assumes that the observations are independent and that the distribution of the difference between measures is symmetric.

${ }^{\mathrm{D}}$ Significant at the $1 \%$ level.

'Significant at the $10 \%$ level,

\subsection{Analyst following}

One proxy variable likely to be related to the production of private information about firms is the number of analysts following their stocks [see, e.g., Bhushan (1989), O'Brien and Bhushan (1990), Shores (1990)]. To test the prediction that the number of analysts following a stock increases after 
options listing, I obtain data on the number of analysts following stocks from the $I / B / E / S$ Summary Tape, produced by Lynch, Jones \& Ryan. [Brown, Foster and Noreen (1984), O'Brien (1988), and O'Brien and Bhushan (1990) also use the I/B/E/S data.] Since the I/B/E/S tape covers the period from January 1976 onwards, I perform these tests on the 88 sample firms listed on options exchanges in 1980 or later.

The I/B/E/S tape provides data on the number of analysts used to compile the consensus earnings forecasts for each firm in each month. I use this as my measure of analyst following and collect for each firm the number of analysts covering the stock one and two years before and after the options-listing month. The results (not reported in tables) are consistent with an increase in analyst following around the time of options listing. In particular, I find that the average number of analysts following these stocks increases from 11.75 twelve months before options listing to 15.39 twelve months after listing (an average of 10.14 analysts follow these stocks two years before options listing, compared to 16.70 two years after listing). ${ }^{9}$

The regression evidence in section 4.1 is consistent with the market's expectation of earnings becoming more precise after options listing. Evidence that the number of analysts following firms increases after options listing, combined with evidence that the forecast accuracy of individual analysts does not change around the time of option listing (table 2), indicates that the increased precision is most likely the result of more analysts following firms after options listing, and is not caused by individual analysts become more informed.

\section{The alternative 'selection bias' explanation}

The results in section 4 are consistent with the notion that options listing increases investors' incentives to collect information about firms, so that the information contained in earnings releases is preempted to a greater extent after options listing. An alternative explanation for these results is that optioned firms change systematically from pre- to post-listing periods, perhaps because of the criteria the options exchanges use to select them. In this section I examine whether optioned firms change through time, and discuss the extent to which these changes explain the earlier results.

Because options exchanges are interested in maximizing options-market trading volume, they have incentives to choose firms with a high level of 'investor interest'. (The options exchanges to not exercise complete discretion with respect to the firms they choose for listing. The SEC requires that stocks

\footnotetext{
${ }^{9}$ This increase is unlikely to be fully explained by an overall upward trend in analyst following. O'Brien and Bhushan (1990, table 4B) report that the average (median) per year change in the number of analysts following stocks on I/B/E/S over the 1981 to 1987 period is $0.7(0.0)$.
} 
underlying options contracts meet requirements such as minimum trading volume and share-price levels, minimum earnings performance, minimum numbers of publicly held shares and shareholders, and so forth.) In examining how these firms change through time therefore, I focus on characteristics that are likely to be correlated with investor interest; namely, recent stockprice performance, cash-flow (earnings) growth and variability, equity betas, and size (market value of equity). ${ }^{10}$ Moreover, previous research documents that the price/earnings relation depends on variables such as firm size [see, e.g., Atiase (1985), Collins, Kothari, and Rayburn (1987)], earnings 'predictability' [Lipe (1990), Pincus (1983)], the existence of growth opportunities [Collins and Kothari (1989)], and equity betas [Easton and Zmijewski (1989)].

Table 5 provides a summary of how each of six variables - relative size, beta, earnings variability, stock-market performance, analysts' forecast errors, and earnings growth - change around the time of options listing for the $\mathbf{2 1 4}$ sample firms. I discuss each of the variables in turn. (For brevity, details of the test procedures are provided in the notes to the table and are not repeated here.)

First, table 5 provides evidence on the relative size and equity betas of these firms in periods before and after options listing. To abstract from market-wide movements in size, I measure relative size as the firm's NYSE market value of equity fractile. I examine firm size because there is evidence that firm size is negatively related to the information content of accounting earnings releases [Atiase (1985), Brown et al. (1987b), Grant (1980)]. An increase in the relative size of optioned firms, therefore, would potentially explain the smaller post-listing announcement effects. I also test for changes in equity betas because the evidence in Easton and Zmijewski (1989) indicates that the size of the price response to earnings releases depends on beta.

The results in table 5 indicate that while these firms' equity betas do not change around the time of options listing, their relative size increases slightly from before to after listing. The average NYSE market value fractile increases from 79.55 before listing to 81.55 after listing, a difference which is statistically significant at the $5 \%$ level. While statistically significant, however, the change is arguably 'small' in economic magnitude - it is difficult to imagine for example that investors' incentives to collect information about firms are affected by an upward shift in the size distribution of two percentage points (the median firm moves from the 86th to the 87th fractile). Nevertheless, there is evidence of an increase in the relative size of these firms, which could partially explain the decline in information content.

\footnotetext{
${ }^{10}$ Firms with above average (risk-adjusted) stock-price performance are more likely to be followed by investors than those that do less well. For example, O'Brien and Bhushan (1990) find that institutional investors are more likely to hold the stock of firms that have performed abnormally well on the stock market.
} 
Table 5

Sample averages (standard deviations) for earnings-announcement-related variables in periods before and after options listing for 214 sample firms.

\begin{tabular}{|c|c|c|c|}
\hline Variable & $\begin{array}{l}\text { Before } \\
\text { options } \\
\text { listing }\end{array}$ & $\begin{array}{c}\text { After } \\
\text { options } \\
\text { listing }\end{array}$ & $\begin{array}{c}\boldsymbol{t} \text {-statistic } \\
\text { for } \\
\text { difference }\end{array}$ \\
\hline $\begin{array}{l}\text { Relatice size } \\
\text { NYSE market } \\
\text { value of equity } \\
\text { fractile }^{\mathrm{a}} \\
(N=209)\end{array}$ & $\begin{array}{c}79.55 \\
(19.44)\end{array}$ & $\begin{array}{c}81.55 \\
(17.71)\end{array}$ & $t=-2.19^{8}$ \\
\hline $\begin{array}{l}\text { Equity betab } \\
(N=190)\end{array}$ & $\begin{array}{c}1.27 \\
(0.49)\end{array}$ & $\begin{array}{c}1.21 \\
(0.44)\end{array}$ & $t=1.68$ \\
\hline $\begin{array}{l}\text { Earnings variability } \\
\text { Average absolute } \\
\text { value of fourth } \\
\text { differences in } \\
\text { quarterly EPS } \\
(N=201)\end{array}$ & $\begin{array}{c}0.85 \% \\
(1.69 \%)\end{array}$ & $\begin{array}{c}1.27 \% \\
(5.21 \%)\end{array}$ & $t=-1.17$ \\
\hline $\begin{array}{l}\text { Earnings growth } \\
\text { Average value of } \\
\text { fourth differences } \\
\text { in quarterly EPS } \\
(N=201)\end{array}$ & $\begin{array}{c}0.22 \% \\
(1.08 \%)\end{array}$ & $\begin{array}{c}-0.51 \% \\
(5.13 \%)\end{array}$ & $t=1.98^{\mathrm{g}}$ \\
\hline $\begin{array}{l}\text { Stock market perfor } \\
\text { Average monthly } \\
\text { abnormal return } \\
(N=190)\end{array}$ & $\begin{array}{c}1.01 \% \\
(1.35 \%)\end{array}$ & $\begin{array}{c}-0.26 \% \\
(1.24 \%)\end{array}$ & $t=8.79^{h}$ \\
\hline $\begin{array}{l}\text { Analyst forecast err } \\
\text { Value Line } \\
\text { forecast errors } \\
(N=2005 \text { before, } \\
N=2093 \text { after })\end{array}$ & $\begin{array}{c}0.05 \% \\
(1.57 \%)\end{array}$ & $\begin{array}{c}-0.06 \% \\
(1.80) \%\end{array}$ & $t=2.13^{\mathrm{g}}$ \\
\hline
\end{tabular}

${ }^{\text {a }}$ To measure relative size, I compute the fractile into which each firm's market value of equity falls in the distribution of the market value of equity of all NYSE firms as of two years before/after options listing. The $t$-statistic is from a single-sample $t$-test of the null hypothesis that the mean difference equals zero. This test assumes that the sample of differences are mutually independent and that they are drawn from a normal distribution.

${ }^{b}$ The equity betas are calculated by fitting the excess-returns version of the market model over the 60-month period before/after options listing. To be included, a firm must have at least 30 months of nonmissing return data. I use the CRSP value-weighted market portfolio as the market-proxy portfolio. The $t$-statistic is from a single-sample $t$-test of the null hypothesis that the mean difference equals zero. This test assumes that the sample of differences are mutually independent and that they are drawn from a normal distribution.

${ }^{c}$ For each firm-quarter observation used in the table 3 tests, I calculate the absolute value of the deflated change in quarterly $E P S, A B S\left[\left(E P S_{t}-E P S_{t-4}\right) / P_{t}\right]$ where $t$ indexes quarters and $P_{t}$ denotes share price as of two days before the earnings-announcement date. I refer to this number as the absolute value of the deflated fourth difference in quarterly EPS and use it here as my measure of earnings variability. In particular, I calculate the average of this number for each firm in each period (before and after listing). The numbers I report above are based on the across-firm distributions of these firm-specific averages. The $t$-statistic is from a single-sample 
Table 5 (continued)

t-test of the null hypothesis that the mean difference equals zero. This test assumes that the sample of differences are mutually independent and that they are drawn from a normal distribution.

${ }^{d}$ For each firm-quarter observation used in the table 3 tests, I calculate the deflated change in quarterly $E P S,\left(E P S_{t}-E P S_{t-4}\right) / P_{t}$, where $t$ indexes quarters and $P_{t}$ denotes share price as of two days before the earnings-announcement date. I refer to this number as the deflated fourth difference in quarterly $E P S$ and use it here as my measure of earnings growth. In particular, I calculate the average of this number for each firm in each period (before and after listing). The numbers I report above are based on the across-firm distributions of these firm-specific averages. The $t$-statistic is from a single-sample $t$-test of the null hypothesis that the mean difference equals zero. This test assumes that the sample of differences are mutually independent and that they are drawn from a normal distribution.

${ }^{e}$ The alpha coefficients (abnormal monthly returns) are calculated by fitting the excess-returns version of the market model over the 60 -month period before/after options listing. To be included, a firm must have at least 30 months of nonmissing return data. I use the CRSP value-weighted market portfolio as the market-proxy portfolio. The $t$-statistic is from a singlesample $t$-test of the null hypothesis that the mean difference equals zero. This test assumes that the sample of differences are mutually independent and that they are drawn from a normal distribution.

${ }^{\text {f }}$ The forecast errors are calculated as the difference between the earnings realization and the most recently available Value Line forecast deflated by stock price two days before the earnings announcement, $\left(E P S_{t}-V_{t}\right) / P_{t}$. The $t$-statistic is from a two-sample $t$-test of the null hypothesis that the mean forecast errors are equal in each period. This test assumes that the two samples comprise independent drawings from normal distributions, but does not assume that the variance of the two distributions are equal.

${ }^{8}$ Difference in means significant at the $5 \%$ level, two-tailed test.

${ }^{\mathrm{h}}$ Difference in means significant at the $1 \%$ level, two-tailed test.

Next, table 5 provides evidence of how the variability of these firms' quarterly earnings changes from pre- to post-listing periods. These tests are important because Lipe (1990) and Pincus (1983) both report evidence consistent with the notion that earnings 'predictability' (measured using the variance of earnings changes) is negatively related to the size of the stock-price reaction to earnings releases.

There is weak evidence that these firms' quarterly earnings series become more variable after options listing: the average size of quarterly earnings changes increases from $0.85 \%$ of stock price before listing to $1.27 \%$ after listing. While the change is not significant under a $t$-test, it is significant using a Wilcoxon signed-ranks test. Even if earnings variability does increase, however, this change is unlikely to explain the decline in measured information content for these firms. Extant evidence indicates that the size of the stock-price reaction to earnings releases is positicely associated with the variability of earnings changes. Therefore, the evidence suggests that an increase in earnings variability would, other things equal, increase the size of the stock price reaction to earnings releases.

Finally, table 5 provides evidence of how three variables that are likely to be correlated with the existence (or not) of economic growth opportunities 
change around the time of options listing. [Collins and Kothari (1989) provide a model in which earnings-response coefficients are positively related to firms' economic growth opportunities.] Firms for which growth opportunities become available are likely to experience abnormally good news. Therefore, I provide evidence on these firms' abnormal stock-price performance, eamings growth, and analyst forecast errors for periods before and after options listing.

The evidence is consistent with these firms realizing abnormally good news before, but not after, options listing. First, these firms earn, on average, abnormal returns of $1.01 \%$ per month in the 60 months before listing. Seventy-eight percent of these firms have positive abnormal returns during this period (149 of the 190 firms with available data). In the five years after listing, however, these firms exhibit slightly negative abnormal performance: the average estimated alpha coefficient for this period is $-0.20 \%(55 \%$ of these firms' alphas are negative). The difference in abnormal performance is significant at the $1 \%$ level using a single-sample $t$-test. Second, based on the Value Line analyst expectations, earnings surprises are, on average, good news before listing but bad news after listing. The average analyst forecast error (as a percentage of stock price) is $0.05 \%$ before listing and $-0.06 \%$ after listing. This difference is significant at the 5\% level using a $t$-test. Finally, I obtain a similar result when I look at the seasonal differences in quarterly earnings (again deflated by stock price). The fourth differences decline from $0.22 \%$ before listing to $-0.51 \%$ after listing, a difference which is also significant at the $5 \%$ level using a $t$-test.

The fact that these firms experience 'good news' before, but not after, options listing is consistent with options exchanges selecting firms that, ex post, experience positive unexpected growth opportunities and thus stockmarket performance. If growth opportunities are positively related to the price response to earnings [as Collins and Kothari (1989) suggest], an alternative explanation for the change in information content is that it is driven by the change in these firms' growth opportunities. To shed more light on this explanation, I partition sample firms into two equal groups according to whether their pre-listing abnormal stock-market performance is above or below the sample median. If the change in information content is driven by a change in growth opportunities, then those firms with the most positive abnormal performance before listing should also be those that experience the largest decline in information content. This is not the case. I find that the decline in information content [whether measured as the change in earningsresponse coefficients (as in section 4.1) or as the change in the size of announcement-period abnormal returns (as in section 4.2)] is not reliably different for the two groups of firms. ${ }^{11}$ This evidence makes is less likely that

\footnotetext{
"I use two-sample $t$ and Wilcoxon tests to assess whether the decline in information content is different for these two sets of firms. In addition, 1 investigate whether there is any correlation
} 
a change in these firms' growth opportunities explains the change in information content.

\section{Discussion and summary}

This paper documents changes in the information content of firms' accounting earnings releases around the time their stocks are listed on options exchanges. In particular, I test the argument that exchange-traded options, when combined with trading in the underlying stock, provide a more costeffective tool for trading on private information than does trading in the stock alone. If options provide a more cost-effective trading vehicle, more private information will be produced about these firms (and impounded into their stock prices) after options-exchange listing, reducing the potential information content of their earnings releases.

Consistent with this explanation, there is evidence that optioned firms are more 'closely followed' after options-exchange listing. For a subsample of optioned firms with available data, I find that the average number of analysts following the stock increases from 10 two years before options listing to 17 two years afterwards.

Further to this, there is evidence that the information content of these firms' earnings releases is lower after options-exchange listing. In particular, I find: (i) that the average coefficient relating earnings-announcement-period abnormal returns to a measure of the earnings surprise declines significantly from 0.69 before options listing to 0.41 after listing, and (ii) that the size of the abnormal returns around earnings-release dates declines, on average, from $2.85 \%$ before options listing to $2.52 \%$ after listing.

One interpretation of this evidence is that described above; that options listing causes these firms to be more 'closely followed' after options listing, reducing the potential information content of their public information releases. It is important to note, however, that while I document an association between options listing and changes in the information content of these firms' earnings releases, it is difficult to draw causal inferences. The incentives of the options exchanges make it unlikely that they select stocks randomly. Therefore, it is plausible that the changes I observe are simply a

\footnotetext{
between the size of the decline in the size of these firms' announcement-period prediction errors (from table 3) and both their abnormal stock-market performance before listing and the change in that performance from before listing to after listing. While the correlation between abnormal performance and the change in information content is small and insignificant $(-0.03)$, the correlation between the change in abnormal performance and the change in information content is reliably negative $(-0.16, p=0.02)$, implying that the change in information content is larger for the firms whose stock-market performance declines the least. This result is opposite that suggested by the growth-opportunities story.
} 
function of the way that options exchanges choose stocks, rather than reflecting the informational effects of options trading.

For example, optioned firms experience abnormally good earnings news (positive analyst forecast errors), positive changes in quarterly earnings per share, and abnormally positive stock-price performance before, but not after, options listing. This is consistent with these firms realizing unexpected economic growth opportunities before options listing. Since economic growth opportunities are positively related to earnings-response coefficients [Collins and Kothari (1989)], a decline in growth opportunities could explain the decline in information content. I also find, however, that the size of these firms' abnormal performance before listing is unrelated to the size of the decline in information content, making this explanation less plausible. (Alternatively, these firms' abnormally positive stock-price performance could cause both the options exchanges' decision to list these firms and their increased following by analysts, which in turn reduces the information content of these firms' earnings releases.)

The results in this study are important in at least two respects. First, my results provide additional information about the role options markets play in the way securities markets produce and process information. In particular, the evidence in this study complements that in Jennings and Starks (1986), who find that the intraday speed of adjustment to earnings releases is quicker for optioned than for nonoptioned firms. Relatedly, this evidence may partially explain why the variance of returns on common stocks declines, on average, after they are listed on options exchanges [see, e.g., Conrad (1989), Skinner (1989)]. If options markets improve the informational efficiency of the stock market, they are also likely to reduce the extent to which 'noise' trading generates volatility in stock-market prices.

Second, several recent accounting studies find that the information content of firms' accounting earnings is negatively associated with these firms' 'information environments' [Atiase (1985), Collins, Kothari, and Rayburn (1987), Freeman (1987), and Grant (1980)]. These studies use firm size as a proxy for 'information environment' and document an inverse relation between size and information content across firms. Following McNichols and Manegold (1983), I extend these studies by documenting a similar inverse relation between the information content of earnings releases and 'information environment' in a different setting.

\section{References}

Atiase, R., 1985, Predisclosure information, firm capitalization and security price behavior around earnings announcements, Journal of Accounting Research 23, 21-35.

Bhushan, R., 1989, Firm characteristics and analyst following, Journal of Accounting and Economics 11, 255-274.

Black, F., 1975, Fact and fantasy in the use of options, Financial Analysts Journal 31, 36-41 and $61-72$. 
Brown, L.D., P.A. Griffin, R.L. Hagerman, and M.E. Zmijewski, 1987a, Security analyst superiority relative to univariate time-series models in forecasting quarterly earnings, Journal of Accounting and Economics 9, 61-87.

Brown, L.D., P.A. Griffin, R.L. Hagerman, and M.E. Zmijewski, 1987b, An evaluation of alternative proxies for the market's assessment of unexpected earnings, Journal of Accounting and Economics 9, 159-193.

Brown, P., G. Foster, and E. Noreen, 1984, Security analyst multi-year earnings forecasts and the capital market, Studies in accounting research no. 21 (American Accounting Association, Sarasota, FL).

Camerer, C., 1989, Bubbles and fads in asset prices, Journal of Economic Surveys 3, 3-41.

Collins, D.W. and S.P. Kothari, 1989, An analysis of intertemporal and cross-sectional determinants of earnings response coefficients, Journal of Accounting and Economics 11, 143-181.

Collins, D.W., S.P. Kothari, and J.D. Rayburn, 1987, Firm size and the information content of prices with respect to earnings, Journal of Accounting and Economics 9, 111-138.

Conrad, J., 1989, The price effect of options introduction, Journal of Finance 44, 487-498.

Cox, J.C. and M. Rubinstein, 1985, Options markets (Prentice Hall, Englewood Cliffs, NJ).

Diamond, D.W. and R.E. Verrecchia, 1987, Constraints on short-selling and asset price adjustment to private information, Journal of Financial Economics 18, 277-311.

Easton, P.D. and M.E. Zmijewski, 1989, Cross-sectional variation in the stock market response to accounting earnings announcements, Journal of Accounting and Economics 11, 117-141.

Foster, G., 1977, Quarterly accounting data: Time-series properties and predictive ability results, Accounting Review 52, 1-21.

Fowler, D.J. and C.H. Rorke, 1983, Risk measurement when shares are subject to infrequent trading: Comment, Journal of Financial Economics 12, 279-283.

Freeman, R.N., 1987, The association between accounting earnings and security returns for large and small firms, Journal of Accounting and Economics 9, 195-228.

Glosten, L. and P. Milgrom, 1985, Bid, ask and transaction prices in a specialist market with heterogeneously informed traders, Journal of Financial Economics 14, 71-100.

Grant, E.B., 1980, Market implications of differential amounts of interim information, Journal of Accounting Research 18, 255-268.

Jennings, R. and L. Starks, 1986, Earnings announcements, stock price adjustment and the existence of options markets, Journal of Finance 41, 107-125.

Lipe, R., 1990, The relation between stock returns and accounting earnings in the presence of alternative information, Accounting Review 65, 49-71.

Marais, M.L., 1984, An application of the bootstrap method to the analysis of squared, standardized market model prediction errors, Journal of Accounting Research 22 (suppl.), $34-54$.

McNichols, M. and J.G. Manegold, 1983, The effect of information environment on the relationship between financial disclosure and security price variability, Journal of Accounting and Economics 5, 49-74.

O'Brien, P.C., 1988, Analysts' forecasts as earnings expectations, Journal of Accounting and Economics 10, 53-83.

O'Brien, P.C. and R. Bhushan, 1990, Analyst following and institutional ownership, forthcoming in the Journal of Accounting Research 28 (suppl.).

Patell, J.M., 1976, Corporate forecasts of earnings per share and stock price behavior: Empirical tests, Journal of Accounting Research 14, 246-276.

Pincus, M., 1983, Information characteristics of earnings announcements and stock market behavior, Journal of Accounting Research 21, 155-183.

Scholes, M. and J. Williams, 1977, Estimating betas from nonsynchronous data, Journal of Financial Economics 5, 307-327.

Shores, D., 1990, The association between interim information and security returns surrounding earnings announcements, Journal of Accounting Research 28, 164-181.

Skinner, D.J., 1989, Options markets and stock return volatility, Journal of Financial Economics 23, 61-78.

Stephan, J.A. and R.E. Whaley, 1990, Intraday price change and trading volume relations in the stock and stock option markets, Journal of Finance 45, 191-220. 